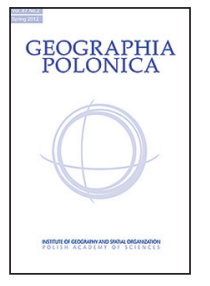 \\ INSTITUTE OF GEOGRAPHY AND SPATIAL ORGANIZATION \\ POLISH ACADEMY OF SCIENCES \\ www.igipz.pan.pl \\ www.geographiapolonica.pl
}

\title{
COMPARISON OF CROSS-BORDER SHOPPING TOURISM ACTIVITIES AT THE POLISH AND ROMANIAN EXTERNAL BORDERS OF EUROPEAN UNION
}

\author{
Delia Bar-Kołelis • Jan A. Wendt \\ Institute of Geography, Faculty of Oceanography and Geography \\ University of Gdańsk \\ Bażyńskiego 4, 80-309 Gdańsk: Poland \\ e-mails: deliabar@kolelis.com • jan.wendt@ug.edu.pl
}

\begin{abstract}
The purpose of the following paper is to debate the cross-border shopping tourism activities taking place at the external borders of the European Union in Poland and Romania. The work focuses on a comparative analyses of three borders from Poland and three borders from Romania. They had a similar history, underwent a period of political and economic transformation and both countries joined the $\mathrm{EU}$ in a short space of time. The research is composed from a theoretical and empirical approach. The theoretical research results show similarities in the evolutions of cross-border shopping tourism activities from both countries. The empirical research updates the situation of cross-border shopping tourism activities. The results show a different evolution of this kind of tourism activities, which has been more predominant at the Polish borders than at the Romanian border, mainly motivated by the stronger market differences existing between Poland and its neighbours, than between Romania and its neighbours. The economic motivators are still strong with a focus of customers on better price benefits and discount opportunities. The leisure elements, although not predominant are present, mainly in Poland, the customers being mainly motivated by the pleasure emerged from the shopping activity. In terms of shopping, the dominant role is played by the shopping, in their old forms (bazaar, local market or a transformed department stores) or their new forms (commercial centres or malls), increasingly incorporating also elements of leisure.
\end{abstract}

\section{Key words}

cross-border shopping $\bullet$ Romania $\bullet$ Poland $\bullet$ border $\bullet$ development $\bullet$ trading $\bullet$ tourism $\bullet$ external border of the European Union

\section{Introduction}

Cross-border shopping tourism activities are outputs of the market differences existing on two sides of a border, motivated by economic, legal or social differences
(Timothy 2005). This niche form of tourism emerged from the activity of travellers engaging in trips outside their local area, crossing their national borders, with the precise purpose of making acquisitions in an adjacent country (Sullivan et al. 2012). This ambiguous 
form of borderland tourism (Timothy 2001) developed in different ways, in different periods of time and at different borders across the globe, having its particularities in Europe (Leimgruber 1988; Minghi 1999; Baláž 2004; Powęska 2008; Tömöri 2010; Wendt 2010; Van der Velde \& Spierings 2010; Bar-Kołelis 2013), in America (DiMatteo 1993; Timothy \& Butler 1995; DiMatteo \& DiMatteo 1996; Arreola 1999; Timothy 2005; Sullivan et al. 2012) and in Asia (Zhao 1994; Wang 2004). These differences are best well reflected in the impact they have as over the local economy

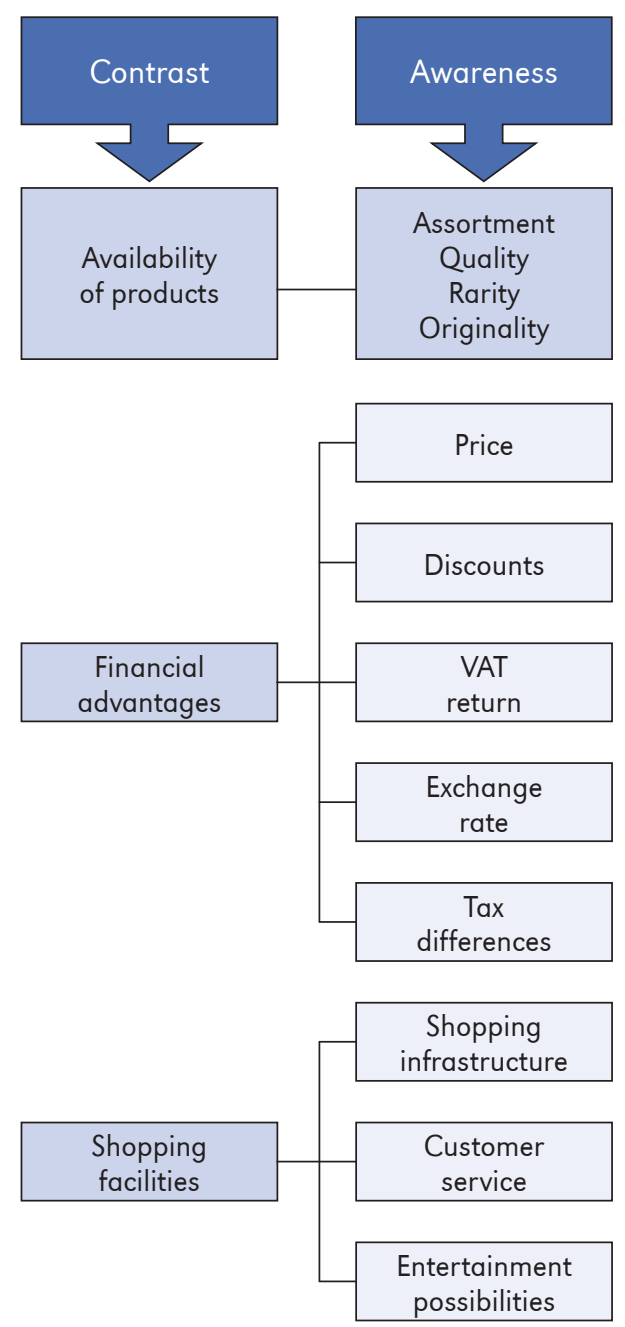

(DiMatteo \& DiMatteo 1996), from different places in the world. Więckowski (2010), underlines the significant socio-economic role played by tourism in the border regions, where it becomes a major element in the local development.

Despite the differences in the output, the common ground for cross-border shopping activities to take place and develop is similar in all location, being divided by Leimgruber (1988) in four basic circumstances that need to be accomplished in order for this phenomenon to take place (Fig. 1):
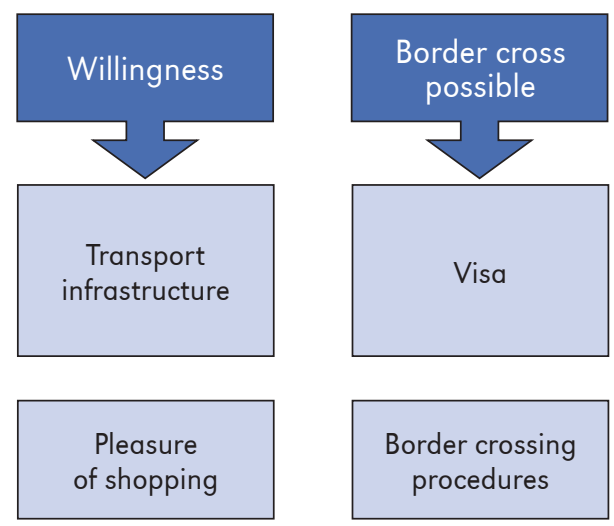

Pleasure of shopping procedures

Figure 1. Conditions and factors for the development of cross-border shopping tourism 
- The contrast in terms of market opportunities connected with the availability of merchandise, prices and shopping locations between the two sides of a border should be visible enough to motivate the people to want to cross the border for acquisitions on the other side.

- The knowledge in terms of market difference existing between the two sides of a border should be spread among local consumers, in order to motivate their willingness and interest for the travel.

- The ability and predisposition of people living in the border areas to travel, directly connected with the available means of transport and the existing infrastructure, should be strong enough in order for them to engage in the travel.

- The border status, which should not be a barrier for the travel, but sufficiently open physically and in the minds of the travellers to make the crossing possible for people and goods.

These four conditions are doubled by a set of factors responsible for giving the direction of cross-border shopping tourism development, overseeing its continuance and influencing its intensity and nature. The factors are politically, socially and economically dependable of the status quo existing in the countries that share a common border, its role, importance and dynamics being differently perceived at different borders.

The differences resulting from the existence of a boundary between two separate state organisms in particular provide a basis for shopping (and shops and shopping centres, including tax-free shopping facilities, on, for instance, ships) (Więckowski 2010). A set of the most common factors influencing cross-border shopping activities was summarised by Timothy (2005) and included the exchange rate, taxation differences, price levels, discounts, assortment and selection of products, customer service, opening hours and entertainment possibilities. Cross-border shopping tourism activities, like other consumption habits that transforms things into commodities (Appadurai 1983), is prone to trends and styles. Along the evolution of cross-border shopping tourism the domination pattern was based exclusively on economic push and pull factors (JansenVerbeke 1990). This trend started to change in the current postmodern era of tourism (Poon 1989), when new push and pull factors emerged based on the need of the demand side to combine leisure and adventure with practical and habitual activities like purchase.

Considering the above mentioned theoretical structure for analysing cross-border shopping activities, the current study focussed on researching the evolution of cross-border shopping activities at six East European borders, three from Poland and three from Romania, that are currently located at the external borders of the European Union. The borders analyses under this current study are: PolishBelarusian, Polish-Russian, Polish-Ukrainian, Romanian-Moldavian, Romanian-Serbian and Romanian-Ukrainian. The choice of Poland and Romania is due to several reasons. There are many similarities. They had a similar history, undergo a period of political and economic transformation. Both countries joined the EU in a short space of time. Border with Ukraine, which allows you to compare crossborder tourism between them on the border with Ukraine, which is encircled both Polish (Lviv region) and Romanian (Transcarpathian region). They have borders with non-EU countries, but also inhabited by the Polish minority (Belarus) and Romania (Moldova) respectively. And the third, analyzed for cross-border traffic between Poland and Romania, borders with Russia (for Poland) and Serbia (for Romania), respectively, allows for a classical analysis of cross-border traffic without the above-mentioned factors.

\section{A recent history of cross-border shopping in Poland and Romania}

In the context of political, economic and social changes that impacted Central and East Europe after the fall of the Iron Curtain, significant changed in consumption patterns in this part of the world took place. The evolution of cross-border shopping tourism activities 
in Poland and Romania from this time, highlights a bigger number of similarities than differences, both countries following a similar path of evolution (Bar-Kołelis 2015). Of course, shopping tourism is also associated with the classic forms of tourism related to recreation, but in the analyzed cross-border traffic is the main factor of travel is the purchase tourism (llieș \& Wendt 2015). In the new politic and economic structure, in both Poland and Romania cross-border shopping pursuits merged with petty trading, developing into the grey economy (Hall 2000) from the beginning of 1990s. This translated into a large number of travellers, with limited capital, chasing advantages emerged from price differences and exchange rates (Williams \& Balaz 2002). The so-called suitcase trade developed remarkably quickly after border restrictions were lifted in this part of Europe, despite the fact that these former countries communist economies were not accustomed to private trading (Hall 2000). The initial cross-border shopping tourists, classified by Holtom (2003) in primitive entrepreneurs, smugglers and traffickers, were in fact the first mass outbound cross-border tourists. Cross-border shopping involves leisure activities and touristic experiences in another country (Timothy 2005; Szytniewska \& Spierings 2017). Tourism proper, as a higher-level good, is still in the initial phase (tourist traffic as defined literally accounts for a couple to a dozen or so per cent of overall cross-boundary mobility), (Więckowski 2010). Cross-border shopping trips are a part of cross-border mobility. The significant growth of the mobility value is clear and obvious. The main types of this kind of trips in Polish borderlands are: recreation short trips, transit, trade and shopping (Więckowski 2008). Cross-border shoppers usually live in relative geographical proximity from a shopping destination, making day-trips possible (Szytniewska \& Spierings 2017).

In Poland, the cross-border shopping tourism activities at the researched borders started in the mid-1980s, and were based on economic and trade reasons (Iglicka 2001). The cross-border trade later developed in the 1990s, when it became a common phenomenon and an important prime or secondary source of income for the families located in these borderlands. The Polish-Belarusian border region fully benefitted from the 'nearthe-border trade and services' economic contacts that 'compensated for the deficit in the official foreign trade' (Komornicki \& Miszczuk 2010: 64). A similar situation took place at the Polish-Russian and Polish-Ukrainian borders, Wallace et al. (1997: 15) describing the phenomenon of Ukrainian, Russian and Belarusian traders in Poland as 'mushrooms after the rain'. The contrast in the market differences that supported trading was created and sustain by the changes taking place in Poland in this period of time, reflected through prices increases, directly favouring petty trading and the 'cross-border' illegal import of cheap products from the neighbouring countries (Wendt \& Ilieș 2004). As business started to flourish for some of the traders this additional source of income became their primary one, petty traders becoming in fact an important drain of human capital, especially in the case of Ukrainians (Williams $\&$ Balaz 2002). The knowledge of the availabilities from the Polish market spread to its neighbouring countries mostly through the word of mouth, stimulated by the social and economic status of the traders.

According to Iglicka (2001) some of the Ukrainian traders who often visited Poland quickly became accustomed to the living standard from the Polish side of the border, expressing the desire to move permanently in Poland. As the political and economic situation stabilised, the cross-border sellers slowly transformed from sellers into shoppers, the products produced in Poland gaining popularity among shopping tourists. Influenced by the market necessities (Iglicka 2001), this new form of trade reflected for many cross-border shoppers travelling to Poland in selling artificially low priced items (like: electric goods, cameras or vodka) and acquiring goods unavailable at home (like clothing items, shoes or electronic equipment). The years between 1994 and 1997 bets reflect this change of direction in terms of acquisitions across the 
Polish borders, with a big number of Belarusians, Ukrainians and Russians coming to Poland mainly to shop (Komornicki \& Miszczuk 2010). However, the trade element still persisted (Wendt 2011; Ilieș \& Wendt 2015). Their willingness of these travellers to engage in the cross-border journey was strongly influenced by factors like the exchange rate, Poland's flexible opening hours and language similarities between Slavic speaking countries. Once the bazaar trade began to be restricted due to changes in consumption patterns, the focus of Belarusian, Ukrainian and Russian consumers was directed more towards acquisitions, the greatest market impact in this matter having the Belarusian shoppers (Iglicka 2001). The new retail developments, built on elaborated retail formulas and sustained by marketing campaigns, became interesting for cross-border shopping activities, in the same way as the shoppers became key customers for the retail locations (Bar-Kołelis 2015).

The flourishing development of cross-border shopping tourism activities at the Belarusian, Russian and Ukrainian borders suffered a setback, once these borders became the external borders of new enlarged European Union in 2004, and later of the Schengen zone. The new configuration of these borders included different procedures and more restrictions that significantly contributed to the decrease of cross-border traffic that according to Komornicki and Miszczuk (2010) was lower in 2008 than in the 1990s. This situation was partially solved by local visa free agreements (like in case of Polish-Russian border) or certain restriction being lifted or eased for some period of time for chosen neighbouring countries (like in case of Ukraine). The particular nature of Belarusian, Russian and Ukrainian cross-border shoppers is emphasised by their similarities, as the research further shows, the nature of their shopping activities in Poland remaining similar from the 1990s up to the present day.

In Romania, the cross-border shopping tourism activities at the researched borders started only after the fall of communist regime in '89. Before that such activities of trading were considered illegal and could be and in some cases were punished by the government, under the charge of "undermining the national economy". The politic and economic situation from the beginning of 1990s, supported by the lift of border restrictions, revealed unlimited opportunities in terms of cross-border shopping and trading (llieș et al. 2011a). Similar to Poland, Romania started by being subject to petty trading from neighbouring countries and becoming in the same time a source of supply for its neighbouring countries. The contrast offered by the Romanian market in comparison to its neighbours was not so obvious in Romania as in the case of Poland, the Romanian market lacking the attractive 'Made in Romania' products after 1989. Therefore, the cross border shopping activities in Romania are more connected with the border characterises and specific politic and economic activities or restriction, influencing these borders. Awareness of the Romanian market in terms of cross-border shopping activities was not so strong like in Poland, but its geographical position and the changes in the political structure of its neighbours, made it attractive.

At the Romanian-Moldavian border, crossborder shopping activities were discouraged by the slight contrasts of the markets in terms of consumers goods, supported by Romanian trade companies that often exported their products in Republic of Moldova. The contrast that existed in terms of earnings, with Romanian earning more and being less interested to shop in Moldova, and Moldavians earning less and not affording to shop in Romania, also discouraged cross-border shopping. The situation started to change after the development of new retail locations in Romania, which began to attract the rich Moldavians, interested in acquiring good unavailable on their local market. The lift of visas, later followed by the local visa free agreement, and the fact that a big number of Moldavians have Romanian passport, allowed for an easy crossing of the border between the two countries and non problematic transportations of goods (Derlaga \& Wendt 2006). 
In the case of the Romanian-Ukrainian border the contrast between the two markets was more prominent, cross-border shopping activities following here a similar path as in Poland, with petty traders coming first to sell and later to acquire. Cities like Botosani or Suceava flourished from cross-border trading and in time the shopping visits of Ukrainians extended beyond the region, Romania becoming a transit country for destinations like Turkey or Bulgaria. The situation changed after Romania joined the European Union, with a new status-quo being created that brought advantages for Romanian tourists travelling into Ukraine, but not for Ukrainian tourists travelling into Romania, proving advantageous to Ukraine tourism to the detriment of Romanian tourism (Ilieș et al. 2011b). Naturally, the cross-border shopping activities from Romania to Ukraine became outbound, while the inbound visits focused mainly on petty traders, coming to sell goods in Romania. The petty trade is maintained active in the borderlands of Romania by the retail structure. In Romania, differently from Poland where after the construction of new retail developments the old ones were mainly abandoned or transform, the new and old retail locations are still functioning. The new retail premises, big, modern shopping centres, often have in their vicinity a bazaar markets, where consumers still shop for cheap products.

At the Romanian-Serbian border the crossborder shopping activities were strongly altered by the political situation from former Yugoslavia, with embargo sanctions imposed on Yugoslavia (Serbia and Montenegro) from 1991 until 1994, and later from 1999 until 2000, by international community (Wendt 2007). What was lost in form of legal trade between Romania and Serbia, was rapidly gained in underground trading, Romania becoming an important smuggling trans-shipment point for Serbia mainly in terms of fuel, but also other commodities. The new cross-border demand, significantly helped in the development of the supply side, poor Romanian towns and communes located near the Serbian border quickly flourishing. The illegal trade continued even after the end of the embargo, a contraband post-embargo era being installed between 2004 and 2007 (Radu 2009). In this period visas were introduced between Serbia and Romania and ordinary people who normally shopped in Romania for cheaper food items, could no longer afford to make the trip as visa costs were too high, compared with their average income (Bar-Kołelis 2015). During this post embargo period the goods were trafficked illegally from one country to another with the help of former fuel contraband dealers (Radu 2009).

The situation changed after border cross restriction were diminished, with Romanians not needing visas to enter Serbia and Serbians received free visas to enter Romania. When legal shopping was allowed and products could be transported without any problems across the border, the interest for cross-border shopping decreased, as the economic situation started to be similar between the two countries. The only exception were the cigarettes, which for taxation reasons became the most illegally trade commodity. Differently from Poland, the Moldavian, Serbian and Ukrainian cross-border shoppers from Romania had little in common in terms of crossborder shopping nature, basing on different needs and market contrast.

\section{Empirical research: The current status of cross-border shopping tourism activities}

The empirical research was built in order to update the situation of cross-border shopping tourism activities taking place at the external borders of the European Union in Poland and Romania, taking in consideration the changing trends in terms of cross-border shopping, reflected in the preference for new, modern retail locations and the involvement of leisure in motivating the travel. The research was conducted in the period 2009-2013, in six main cities located in the border regions under analyses: Bialystok at the Polis-Belarusian border, Gdańsk at the Polish-Russian border, Lublin at the Polish-Ukrainian border, lasi at the 
Romanian-Moldavian border, Timisoara at the Romanian-Serbian border and Suceava at the Romanian-Ukrainian border. The research was based on an interdisciplinary approach, the primary source of data being the cross-border shoppers from Belarus, Russia, Ukraine, Moldavia and Serbia. The researched, based on primary data that were collected using a pen and paper questionnaire surveys. A purposive non-random sampling method was used as research tool for both quantitative and qualitative methods, due to limitation in predicting the total amount of population and for increasing the probability of results by eliminating from population the units that had no knowledge of the subject. The research focused on comparing the basic circumstances for cross-border shopping activities.

\section{Market contrast}

The research target was to evaluate the market contrast between the market offer available in Poland and Romania, vs. the market offer available in the origin countries of crossborder shoppers. For this analyse the units were asked to mark on a scale from 1 to 5 the differences between the two markets, 1 meaning much better at home, 2 better at home, 3 the same, 4 better at destination and 5 much better at destination.

In Poland (Fig. 2), Belarusians, Russians and Ukrainians evaluated the market differences connected with the availability of products and financial advantage as better or much better at destination than at home. In terms of shopping facilities connected with availability of modern retail spaces, customer service and entertainment facilities, the situation was evaluated as better or the same at destination like at home, while in terms of available shops the situation was evaluated as better at destination.

In Romania (Fig. 3), the Moldavians evaluated the market differences and financial advantages a little better at destination than at home, while the Serbians evaluated them as similar. The Ukrainians evaluated both

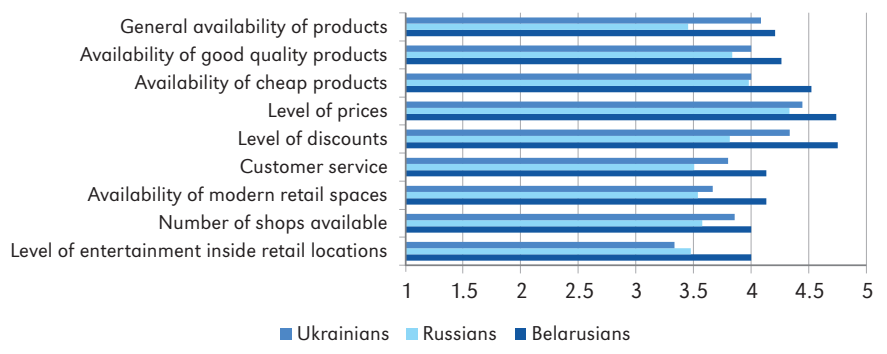

Figure 2. Market contrast between Poland and its neighbouring countries evaluated by cross-border shoppers - synthetic indicators

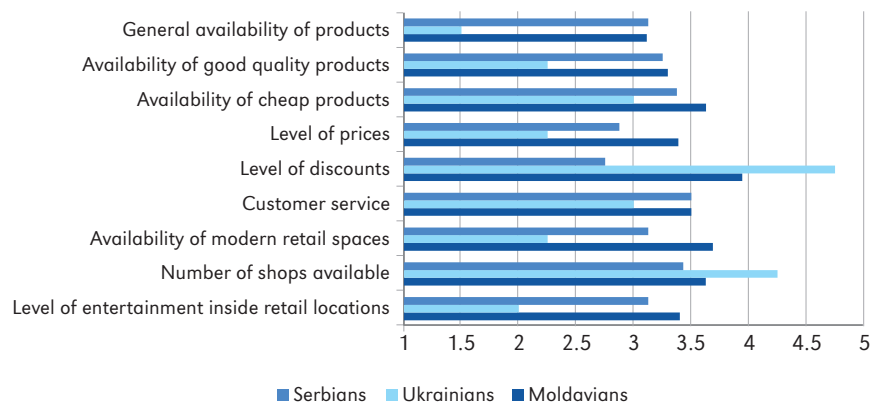

Figure 3. Market contrast between Romania and its neighbouring countries evaluated by cross-border shoppers - synthetic indicators 
market differences and financial advantages as better at home than at destination, while in terms of shopping facilities, the situation was evaluated as similar. From the perspective of cross-border shoppers from outside the European Union, the contrast between the overall offer from their local market is stronger in case of Poland than in case of Romania.

\section{Awareness of cross-border shoppers, travel infrastructure and border crossing accessibility}

The majority of the cross-border shoppers declared that they know about the shopping opportunities that exist on the other side of the border from other shoppers, a small declaring that they got informed through internet and commercial campaigns (Fig. 4).
Among the cross-border shoppers was noticed a positive predisposition for travel, the majority of them choosing their own car as transport mean when they travelled across the border for shopping (Fig. 5).

In terms of transport infrastructure, the units were asked to evaluate the difficulties they face in terms of infrastructure when they travel to Poland, respectively Romania. The evaluation was done on a scale from 1 to 5 , where 1 means very low difficulties, 2 low difficulties, 3 average difficulties, 4 high difficulties and 5 very high difficulties. The research results show that the infrastructure does not pose a problem for the development of crossborder shopping tourism activities, most travellers declaring to face lower difficulties in this matter (Fig. 6).

In terms of border crossing accessibility, the situation was analyzed in terms of visas and border crossing procedures, the units being

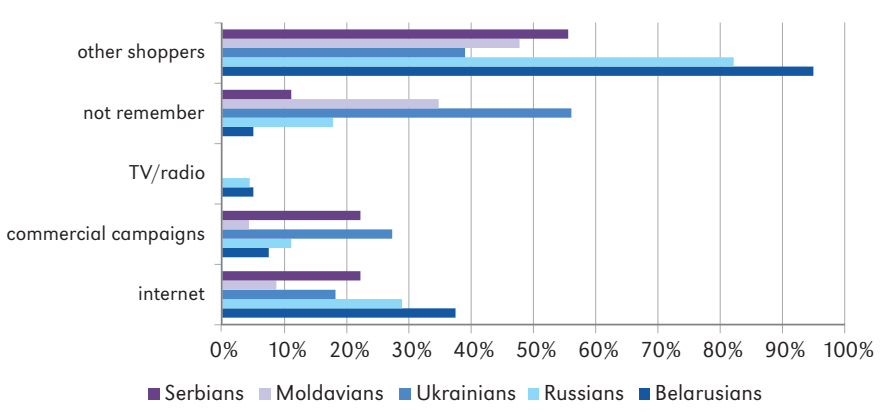

Figure 4. Awareness of cross-border shopping opportunities in Poland and Romania

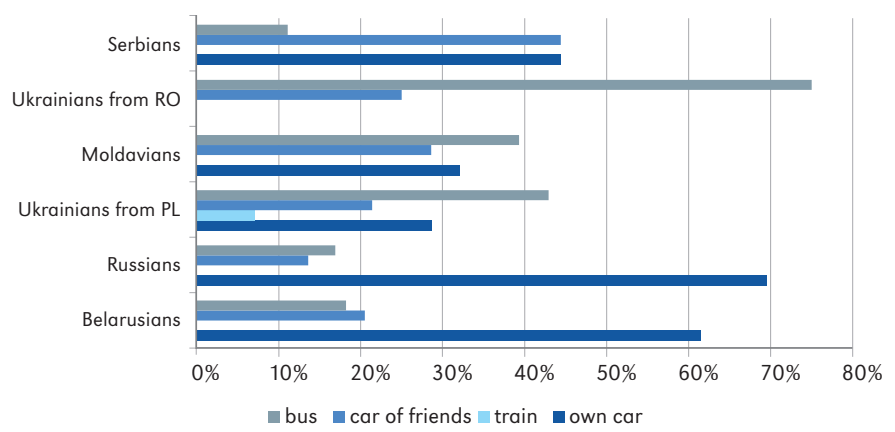

Figure 5. Means of transport used by cross-border shoppers from Poland and Romania 


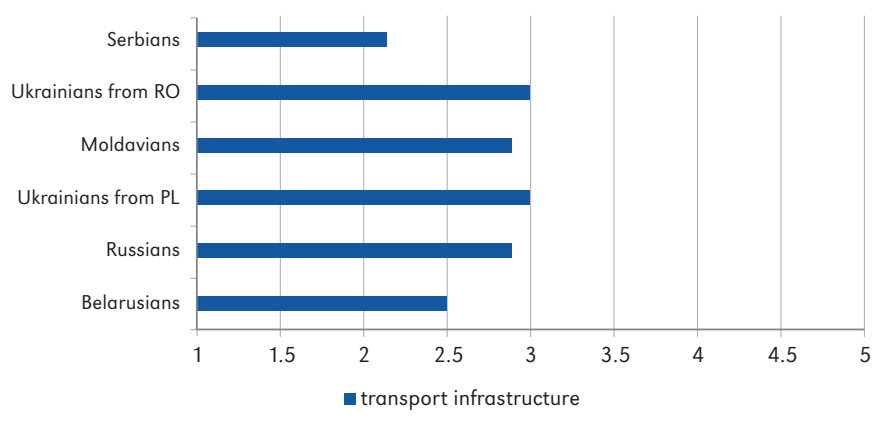

Figure 6. Transport infrastructure difficulties for cross-border shoppers in Poland and Romania - synthetic indicators

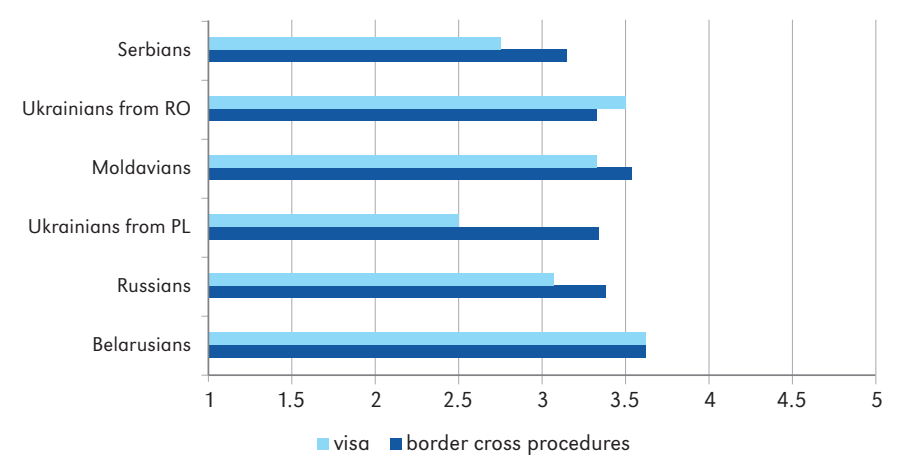

Figure 7. Evaluation of border crossing accessibility by cross-border shoppers Poland and Romania synthetic indicators

asked to evaluate this elements when travelling to Poland, respectively Romania. The evaluation was done on a scale from 1 to 5 , where 1 means very low difficulties, 2 low difficulties, 3 average difficulties, 4 high difficulties and 5 very high difficulties. All respondents declared that they face above average difficulties in terms of border crossing procedures (Fig. 7). The highest difficulties connected with visa were signalised Belarusians, Ukrainians shopping in Suceava, Moldavians and Russians. The lowest difficulties were signalised by the Serbians and Ukrainians shopping in Lublin.

The research results revealed that in current times the cross-border shopping tourism activities have better basis to develop in Poland than in Romania in terms of market contrast, although the border crossing procedures to enter Poland are more problematic.

\section{New trends in cross-border shopping in the borderlands}

The increase of modern retail supply in the border regions positively stimulates cross-border shopping tourism activities, as cross-border shoppers prefer modern shopping retail locations (supermarkets and commercial centres). Shopping tourism became a significant tourist activity in some border regions developing around outlet shopping centres or mega malls as tourist destinations. Commercial centres are important attraction sites for tourists, offering a variety of features from playgrounds and theme parks, to restaurants and hotels or financial services (Lew, et al., 2008). In the Polish and Romanian borderlands the elements of leisure, prestige and quality associated with new or renewed retail spaces 
were key factors that demanded measurement and evaluation, therefore the research focused strictly on shops located inside commercial centres, eliminating street or bazaar shops. The research results show that in terms of shopping destinations all respondents prefer modern retail locations that offer them choice in terms of merchandising and prices, supermarkets/hypermarkets and commercial centres representing the preferred shopping locations for all respondents. The research results also show that the shopping infrastructure is an important or very important shopping motivator for respondents from Białystok, Gdańsk and Lublin, where the shopping activities were reported as most intense. It is important to note that apart from the retail infrastructure, a key element in attracting cross-border shoppers in the research area is good customer service, this being a major motivational factor for respondents from both Poland and Romania.

In East and Central Europe the key roles in consumption are played by supermarkets/ hypermarkets. In terms of shopping, the dominant role is played by the shopping, in their old forms (bazaar, local market or a transformed department stores) or their new forms (commercial centres or malls), increasingly incorporating also elements of leisure (Dopierała \& Kołelis 2012; Rochmińska 2016). The local retail market has undergone a long transition period, which from the aspect of the city retail structure it is not over yet. The city bazaar and open-air shopping locations are sited near new and modern commercial centres, representing a big competition to them. This transitional retail character had a strong impact on the city's commerce, especially after 2009, when, due to the financial crisis, many businesses went bankrupt, this including also new retail locations.

The Russian cross-border shopping tourism activities in Gdańsk are popular, commercial centres managers and retailers being well accustomed to this. The commercial centre managers reported having Russian shoppers among their customers, and being regular ones. When interviewed, the shopping centres representatives described Russian shoppers as daily customers, their visits being more preponderant during the weekend, especially on Saturday (Bar-Kołelis 2015). In other areas as in Romania shows that cross-border shopping tourism activities undertaken by Ukrainians in Suceava are rare. Commercial centre managers and shop assistants are aware of the phenomenon because it used to be popular before Romania joined the European Union.

In the opinion of the commercial centres representatives, shopping tourism activities undertaken by Ukrainian shoppers in Suceava were already common before 1990s and continued until the beginning of the years 2000 . The cross-border shopping activities taking place in that period were strongly focused on trade, which involved the acquisitions of goods from Suceava or other cities located further away such as Piatra-Neamt, with the aim of reselling them in Ukraine. This phenomenon started to lose intensity and alter in nature when market differences between Romania and Ukraine significantly changed in light of Romania's accession to the European Union, much to the detriment of the Romanian market. The latter, now, became unattractive for Ukrainian shoppers, while the benefits offered by the Ukrainian market attracted a flow of Romanian shoppers. According to the commercial centres representatives, currently the level of cross-border shopping activities undertaken by the Ukrainian tourists in Suceava is very low, these customers being more accidental or in search of specific otherwise traditional products. The commercial centres representatives reported that products brought from Ukraine are very popular in Suceava, these include food items, clothes, detergents and electronic and electric devices. Ukrainian tourists regularly bring products from their local market to Suceava, which are then sold in the local open market by the local merchants.

In the case of cross-border shopping activities undertaken by the Serbian tourists in Timisoara, the research results show that all four categories of motivational factors are active motivators, the most important ones being the quality of products, indirect financial 
advantages and customer service. The fact that the motivational factors are active, but the shopping tourism activities are minimal, can be explained by the strong market similarities in terms of products, prices and retail facilities. The predisposition for cross border shopping activities exists among Serbian shoppers; however, the market differences are not sufficiently significant to support this phenomenon as a regular activity. It is also important to underline that number of the units III (cross-border tourists) taking part in the research in Timisoara was small. This limited accessibility to data could influence the research results in terms of motivation for cross-border shopping activities of Serbians in Timisoara.

\section{Conclusion}

The results of the above analyses show a different evolution of cross-border shopping tourism activities in Poland than in Romania, with a big number of evolution similarities, but also differences in nature and development stages. In Poland, the cross-border situation at the three borders analysed was very similar in the beginning of 1990s, this similarity continuing in current times, similarly evolving and developing. In the beginning the trading was core of cross-border shopping, while now later acquisition became the main focus, elements of leisure being gradually introduced in the expectations of the cross-border consumers.

In Romania, the cross-border situation evolved differently at the three borders analysed, each of them having and continuing to have its particularities. While at the Romanian-Moldavian border the new retails developments stimulated the inbound cross-border shopping, at the Romanian-Ukrainian border the modern retail premises stimulated the development of a cheaper alternative given by outbound cross-border shopping. At the Romanian-Serbian border the intense crossborder traffic generated by the embargo and post embargo periods was followed by a period with low traffic, which currently persists, as the consumers necessities and demands deed to reconfigure in this new retail structure.
Both Poland and Romania have a lot in common in terms of cross-border shopping, these similarities being more prominent in the past, when the retails structures were very alike, being at a similar level of development. In the years that followed, Poland developed faster than Romania, using the possibility of creating and promoting its 'Made in Poland' brand in terms of fast consumer goods, the core of cross-border shopping acquisitions. These elements helped Poland to stay attractive for cross-border shoppers, which expectations evolved in the same time with the evolution of Polish retail structure. Therefore, the transition from trading to shopping and leisure is almost completed for cross-border shoppers. In Romania the development started later, emerging in the form of an economic boom, to which not all the consumers rapidly adapted. In this context the cross-border activities suffered big discrepancies from one border to the other, in one location trading motivating the travel, while in another locations appeared the need for sophisticated shopping and leisure. The transition period from trading to shopping and leisure it still an ongoing process in Romania, partially completed, but far from finish.

\section{Editors' note:}

Unless otherwise stated, the sources of tables and figures are the authors', on the basis of their own research. 


\section{References}

Appadural A. (ed.), 1988. The social life of things: Commodities in cultural perspective. Cambridge: Cambridge University Press.

Arreola D.D., 1999. Across the street is Mexico: Invention and persistence of the border town curio landscape. Yearbook of the Association of Pacific Coast Geographers, vol. 61, pp. 9-41.

BALÁŽ V., 2004. Slovakia: EU accession and crossborder travel [in:] D. Hall D., M. Smith, B. Marciszewska (eds.), Tourism in the new Europe: The challenges and opportunities of EU enlargement, London: CABI Publishing, pp. 92-103.

BAR-KotelIS D., 2013. New retail locations and cross-border shopping in Poland. Journal of Geography, Politics and Society, vol. 3, no. 1, pp. 19-32.

Bar-Kotelis D., 2015. Shopping tourism on the eastern borders of the European Union. Gdańsk: University of Gdańsk [PhD thesis, typescript].

Derlaga A., Wendt J., 2006. Cross-border co-operation between the Republic of Romania, Ukraine and Moldova [in:] J. Kitowski (ed.), Regional transborder co-operation in countries of Central and Eastern Europe - a balance of achievements, Geopolitical Studies, no. 14, Warsaw: Institute of Geography and Spatial Organization PAS, pp. 141-158.

DıMATTEO L., 1993. Determinants of cross-border trips and spending by Canadians in the United States: 1979-1991. Canadian Business Economics, vol. 1, no. 3, pp. 51-61.

DiMatteo L., DiMatteo R., 1996. An analysis of Canadian cross-border travel. Annals of Tourism Research, vol. 23, no. 1, pp. 103-122.

Dopierata Ł., BAR-Kotelis D., 2012. Malbork revitalization process. Geographia Napocensis, vol. 6, no. 1, pp. 21-30.

HaLl D., 2000. Cross-border movement and the dynamics of transition processes in Southeastern Europe. GeoJournal, vol. 50, no. 2, pp. 249-253.

Holtom P., 2003. Coping with the future of the small-scale cross-border traders in Kaliningrad's borderlands [in:] H-M. Birckenbach, C. Wellmann (eds.), The Kaliningrad challenge options and recommendations, Munster: LIT Verlag, pp.152-168.

IGLICKA K., 2001. Shuttling from the former Soviet Union to Poland: From 'primitive mobility' to migration. Journal of Ethnic and Migration Studies, vol. 27, no 3, pp. 505-518.
ILIES A., Wendt J.A., 2015. Geografia turystyczna. Podstawy teorii i zagadnienia aplikacyjne. Gdańsk: Wydawnictwo Uczelniane Akademii Wychowania Fizycznego i Sportu.

Ilieș A., Ilieș D., Wendt J., Tătar C., 2011a. Elements and outils generating systemic functionality at Romanian/Ukrainian border(Northern sector). Journal of Geography, Politics and Society, year 1, no. 1, pp. 15-23.

Ilieș, A., Ilieș, D.C., Morar, C., Ilieș, M., 2011 b. The permeability of the Romanian border and the international tourism movement in the period 1994-2008. Revista Romana de Geografie Politica, Year 13, no. 2, pp. 237-246.

Jansen-Verbeke M., 1990. From leisure shopping to shopping tourism [in:] Proceedings of the International Sociological Association Annual Conference, Madrid: International Sociological Association, pp. 1-17.

Komornicki T., Miszczuk A., 2010. Eastern Poland as the borderland of the European Union. Quaestiones Geographicae, vol. 29, no. 2, pp. 55-69.

LEIMgRUBeR W. 1988. Border trade: The boundary as an incentive and an obstacle to shopping trips. Nordia, vol. 22, no. 1, pp. 53-60.

MINGHI J.V., 1999. Borderland 'day tourists' from the East: Trieste's transitory shopping fair. Visions in Leisure and Business, 17, vol. 4, pp. 32-49.

Poon A., 1989. Competitive strategies for new tourism [in:] C. Cooper (ed.), Progress in tourism recreation and hospitality management, vol. 1, London: Belhaven Press, pp. 91-102.

POWESKA H., 2008. The character and conditions for development of cross-border shopping in Poland in the period of transformation. Electronic Journal of Polish Agricultural Universities, vol. 11, no. 4, pp.65-74.

RADU C., 2009. Border tricksters and the predatory state: Contraband at the Romania-Serbia border during the Yugoslavian embargoes. Focaal-European Journal of Anthropology, no. 54, pp. 49-63.

RoCHMIŃSKA A., 2016. Shopping centres as the subject of Polish geographical research. Geographia Polonica, vol. 89, no. 4, pp. 521-535

Suluivan P., Bonn M.A., Bhardwa V., DuPont A., 2012. Mexican national cross-border shopping: Exploration of retail tourism. Journal of Retailing and Consumer Services, vol. 19, no. 6, pp. 596-604. 
Szytniewska B., Spierings B., 2017. Place image formation and cross-border shopping: German shoppers in the Polish bazaar in Stubice. Tijdschrift voor economische en sociale geografie, DOI: 10.1111/tesg.12283.

TIMOTHY D.J., 2005. Shopping tourism, retail and leisure. Aspects of Tourism, 23, Clevedon-Buffalo: Channel View Publications.

Timothy D.J., Butler R.W., 1995. Cross-border shopping: a North American perspective. Annals of Tourism Research, vol. 22, no. 1, pp.16-24.

TIMOTHY D.J., 2001. Tourism and political boundaries. London: Routledge.

TöMÖRI M., 2010. Investigation shopping tourism along the borders of Hungary: A theoretical perspective. GeoJournal of Tourism and Geosites, vol. 6, no. 2, pp. 202-210.

van der Velde M., Spierings B., 2010. Consumers mobility and the communication of differences: Reflecting on cross-border shopping practices and experiences in the Dutch-German borderland. Journal of Borderlands Studies, vol. 25, no. 3-4, pp. 191-205.

Wallace C., Sidorenko E., Chmouliar O., 1997. The Central European buffer zone. Vienna: Institute for Advanced Studies, University of Derby UK.

Wang D., 2004. Hong Konger's cross-border consumption and shopping in Shenzhen: patterns and motivations. Journal of Retailing and Consumer Services, vol. 11, no. 3, pp. 149-159.

WENDT J., 2004. Przestrzenne zróżnicowanie i uwarunkowania przenikania systemu demokratycznego w Polsce i w Rumunii. Warszawa: Carta Blanca.
WendT J., 2005. Wspótpraca euroregionalna Mołdawii i Rumunii [in]: W. Kosiedowski (ed.), Regiony Europy Środkowej i Wschodniej wobec globalizacji i integracji międzynarodowej, Włocławek: UMK, pp. 197-203.

WENDT J., 2007. Romanian Euroregions in the process of European integration - case study of the Serbian border [in:] M. Koter, K. Heffner (eds.), Regions in the process of European integration, Łódź-Opole: Region and Regionalism, vol. 2, no. 8, pp. 17-26.

WeNDT J., 2010. Changes on East neighbors tourism in Poland [in:] J. Wendt (ed.), Chosen problems of geographical research in Poland and Romania, Oradea: Universitatea din Oradea, pp. 9-16.

WendT J., ILIEȘ A., 2004. Kaliningrad: region de menace ou de cooperation? [in:] Y. Richard, A.L. Sanguin (eds.), L'Europe de l'Est quinze ans apres la chute du mur, Paris: L'Harmattan, pp. 35-40.

WENDT J.A., 2011. Zarys geografii turystycznej. Gdańsk: Wydawnictwo Uniwersytetu Gdańskiego.

WIECKOWSKI M., 2008. New international mobility of Poles. Espace, Populations, Societes, 2, pp. 261-270

WIĘCKOWSKI M., 2010. Tourism development in the borderland of Poland. Geographia Polonica, vol. 83, no. 2, pp. 67-81

WILLIAMS A.M., BALAZ V., 2002. International petty trading: Challenging practices in trans-Carpathian Ukraine. International journal of Urban and Regional Research, vol. 26, no. 2, pp. 323-342.

ZHAO X., 1994. Barter tourism along China-Russia border. Annals of Tourism Research, vol. 21, no. 2, pp. 401-403. 